\title{
Altered therapeutic response towards inhaled corticosteroids in asthmatics -smokers with mild asthma
}

\author{
Zoran Arsovski ${ }^{1 *}$, Dejan Dokic ${ }^{1}$, Zlatica Gosheva ${ }^{1}$, Elena J. Janeva ${ }^{1}$, Anita Arsovska $^{2}$, \\ Viktor Isjanovski ${ }^{3}$
}

${ }^{1}$ University Clinic of Pulmonology and Allergology, Medical Faculty, University Ss Cyril and Methodius, Skopje, Majka Tereza, 17, 1000 Skopje, R. Macedonia

${ }^{2}$ University Clinic of Neurology, Medical Faculty, University Ss Cyril and Methodius,

Majka Tereza, 17, 1000 Skopje, R. Macedonia

${ }^{3}$ Psychiatric Hospital Skopje, Medical Faculty, University Ss Cyril and Methodius,

Proleterska bb, 1000 Skopje, R. Macedonia

Received: August 2016; Accepted: October 2016

\begin{abstract}
The exposure to tobacco smoke could cause bronchoconstriction and acute asthma attack. Smoking asthmatics have an insufficient therapeutic response to the standard therapy and unsatisfactory improvement of the respiratory function.

In a randomized parallel study, a therapeutic response to inhaled fluticasone propionate in a dose of $250 \mu \mathrm{g}$ twice per day was determined in 38 asthmatics with mild asthma, smokers and nonsmokers. Short-acting 32 agonist (salbutamol) in a dosage of $0.1 \mathrm{mg} / \mathrm{per}$ inhaled dose was used as a rescue medication when needed. In patients, asthma was detected with a positive metacholine test and/or positive bronchodilatator response of $>12 \%$ with $\geq 200 \mathrm{ml}$ increase of FEV1. They were randomized in two groups according to sex, age and starting values of FEV1. Before and after 6 weeks of treatment with fluticasone propionate of the previously corticosteroid-naive patients, lung function test (spirometry) was performed.

A statistically significant effect $(\mathrm{p}<0.05)$ was achieved during the fluticasone propionate therapy in a group of non-smoking asthmatic patients. The same effect was not seen in the group of smoking asthmatics. Although the percentage of elevated FEV1 values was small, it was satisfactory because of the starting FEV1 values in patients with mild asthma.

More studies are needed in asthmatics determining the asthma symptom score, the number of night awakenings due to asthma, the asthma exacerbations and the frequency of rescue therapy usage which will define the altered therapeutic response to inhaled corticosteroids in smoking asthmatics.
\end{abstract}

Keywords: asthma, spirometry, inhaled corticosteroids

\section{Introduction}

According to the World Health Organization in 2015, there were 1.1 billion smokers in the world, and although it has been a declining habit worldwide, the prevalence is increasing in the Eastern Mediterranean region and Africa.
The prevalence in Europe in 2012 was 39\% among men and $19.3 \%$ among women aged 15 and more (Global Health Observatory data, 2015). The active tobacco smoking is associated with poor asthma control among adults whereas the passive smoking (environmental tobacco smoke) is the reason for wheezing in childhood associated with asthma. Smoking is a trigger factor for asthma attacks. In most of

\footnotetext{
*arso66@yahoo.com
} 
the developed countries approximately $17-35 \%$ from the asthmatics are smokers (Thomson et al., 2004).

The following factors contribute towards reduced respiratory function among active smokers with asthma: the number of smoked cigarettes, the presence of wheezing, low body mass, a low forced expiratory volume in $1 \mathrm{sec}-$ ond (FEV1) or a low ratio between FEV1 and FVC where FVC represents forced vital capacity, additional professional exposition and air pollution. Also, smokers with asthma had also reduced compliance (i.e. the patients were not using the prescribed drugs because of the feeling that they did not have any effect). Apostol et al. in 2002 conducted a research with 4000 adults from 18 to 40 years old, evaluating the decline of FEV1 over a ten year period. It has been established that among non-smokers without asthma the annual decline in FEV1 was 8.5\%, among non-smokers with asthma $10.1 \%$, among smokers without asthma $11.1 \%$ and the highest decline of FEV1 was detected among smokers with asthma: $17.8 \%$. Faster decrease of FEV1 in asthmatic smokers compared to asthmatics who do not smoke has also been detected in other studies (Tamimi et al., 2012; Viegi et al. 2003). However, among smokers with asthma that stopped smoking, after the first week, a statistically significant increase in FEV1 was noticed (Chaudhuri et al., 2006 ). In ex-smokers and non-smokers with asthma, Thompson and Spears found improvement of FEV1 and asthma control (Thomson and Spears, 2005). Tonnesen and his coworkers (Tonnesen et al., 2007), also found that if the patient had stopped smoking, the rate of decline of FEV1 significantly decreased similar to a non-smoker. However, despite a possible increase of FEV1 after smoking cessation, FEV1 would never reach the values of a never-smoker.

According to Chalmers and his coworkers (Chalmers et al., 2001) asthmatic smokers have an increased number of cells in the bronchoalveolar lavage, in which neutrophils are more prevalent, in contrast to non-smoking asthmatics; while the number of eosinophils has a decrease in percentage among asthmatic smokers compared to asthmatic non-smokers. The guidelines for treatment of bronchial asthma recommend the inhaled steroids as the most effective anti-inflammatory treatment of asthma (National Heart, Lung and Blood Institute and world Health Organization. National Asthma Education Program, 1997; BTS/ SIGN,2003). It was shown that the inhaled steroids reduce the symptoms and the exacerbations and they improve the respiratory function (Barns and Ulrik 2015; Barnes et al., 1998). They lead to a reduction of the risk for death from asthma (Barnes et al., 1998; Lanes et al., 2002).

The aim of the study was to evaluate the altered therapeutic response to the recommended average therapeutic doses of fluticasone propionate on the respiratory function among smokers with mild asthma. Objectives of the study were to determinate the difference between FEV1 before and after inhaled corticosteroid treatment in smokers and nonsmokers with mild asthma.

\section{Material}

In a randomized, parallel study an investigation was done with 38 asthmatics with mild asthma. Among patients, within the age group of 18-50 years asthma was detected with previously positive dose-provoking methacholine test and/or a positive bronchodilator response from $>12 \%$ with $\geq 200 \mathrm{ml}$ increase in FEV1. The age of the patients included was limited to 50 years, in order to avoid the inclusion of patients with COPD. Because of the same reasons, patients that smoke more than 40 cigarettes per day or patients that have been smoking more than 15 years have not been included.

The patients were randomized in two groups, according to gender, age and starting FEV1, group of smokers and non-smokers, among which the therapeutic response to inhaled fluticasone propionate was determined. Considered for non-smokers were persons who have never smoked, or have been smoking only for two years during their whole life, or stopped smoking at least one year before the examination. Considered for smokers were those who smoke 10-40 cigarettes per day or had a smoking history of 2 to 15 years, but without diagnosis of COPD.

\section{Design of the study}

At the beginning of the research, demographic information, information regarding the beginning and duration of the asthma, symptoms of the disease, past diseases, family, social and pharmacological anamnesis were obtained from the history of the patient. All patients who smoked were advised to stop smoking, but those who refused were included in the study as asthmatic smokers. During the study, the condition of the patients was followed by outpatient monitoring.

In all patients, previously untreated with inhaled corticosteroids, the spirometric tests were made by using a Power-Cube spirometer. Tests were done before and after 6 weeks of treatment with fluticasone propionate. Patients were treated according to the criteria and recommendations of the Global Initiative for Asthma (GINA) and according to adopted national programs for the treatment of asthma in the Republic of Macedonia (Global Initiative for Asthma, GINA, 2017).

The therapeutic response to inhaled fluticasone propionate, measured by FEV1 was determined among patients at a dose of $250 \mu \mathrm{g}$ twice a day (total daily dose of $500 \mu \mathrm{g}$ ). As a facilitator drug, a short-acting $\beta 2$ agonist - bronchodilator, salbutamol from $0.1 \mathrm{mg}$, per inhaled dose, was used if needed. FEV1 was expressed in percentage from the predicted normal value for each person according to race, gender, age, height and weight.

For statistical analysis descriptive methods, a method with mean value, standard deviation, Mann Whitney test and confidence interval of $95 \%(\mathrm{p}<0.05)$ were used. 


\section{Results}

Pulmonary function was analyzed in a group of 38 patients with mild asthma, 16 smokers and 22 non-smokers (Fig.1).

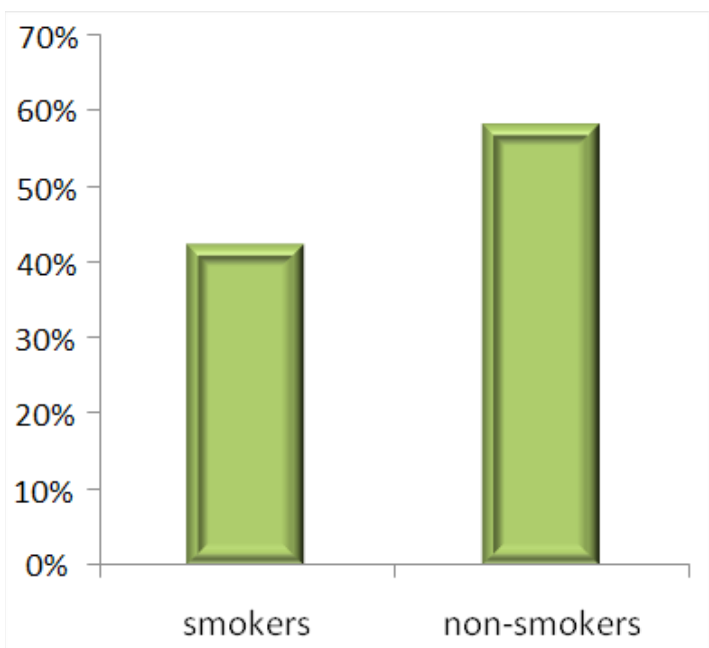

Fig. 1. Smokers and non-smokers with asthma.

There is no significant difference obtained between the two groups according to the age and the values for FEV1 before the beginning of the examination (Table 1; Fig. 2).

There is no statistically important difference between the values for FEV1 before the beginning of the examination (Table 2; Fig. 3).

After six weeks of treatment with inhaled fluticasone propionate with a dose of $250 \mathrm{mg}$ twice per day (a total daily dose of $500 \mathrm{mg}$ ), a statistically significant positive effect for FEV1 $(p<0.05)$ was obtained from the therapy

Table 1. Age distribution of asthmatic patients

\begin{tabular}{|c|c|c|c|}
\hline Mean & Mean & Valid N Valid N & J Std. Dev. Std. Dev. \\
\hline 27.77273 & 28.62500 & 16 & 6.3014124 .631414 \\
\hline
\end{tabular}

Mann-Whitney U test $(\mathrm{p}=0.6693)$

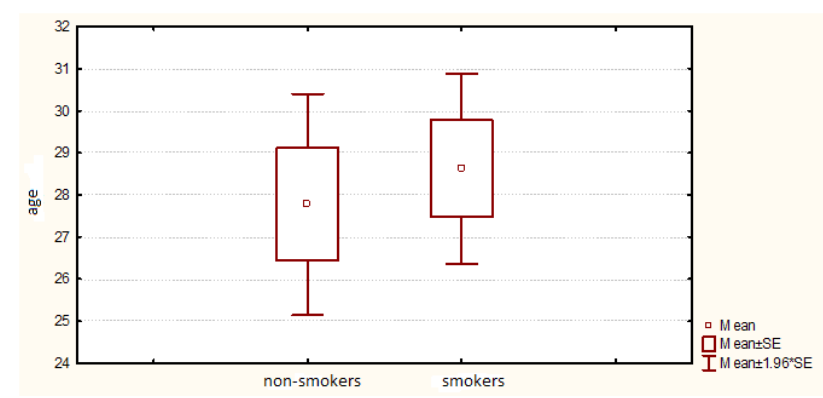

Fig. 2. Age distribution of asthmatic patients. with fluticasone propionate among the group of asthmatic non-smokers compared to the effect of the therapy for the group of asthmatic smokers (Table 3; Fig. 4). Although the values of FEV1 given in percentage of improvement are small, they are satisfactory for initial spirometric values of patients with mild asthma.

As in our survey, the perceived reduced benefit of corticosteroid therapy among the asthmatics exposed to cigarette smoke due to reduced sensitivity has also been demonstrated in several other studies, starting in 1996 by Pedersen and his coworkers (Pedersen et al., 1996). They found out that within 3 months of treatment with inhaled corticosteroid (ICS) - budesonide at a dose of $1600 \mathrm{mg}$ per day, there was an excellent response among non-smoking asthmatics, with statistically significant increase of FEV1, but this effect was completely absent among the asthmatic smokers, treated with the same product during the same period of time. Tomlison and coworkers (Tomlinson et al., 2005) during a 12 week survey, demonstrated that up to $2000 \mathrm{mg}$ per day of inhaled (inhalation) beclomethasone was necessary among asthmatic smokers in order to achieve some positive effect on the peak expiratory flow - PEF, but even that effect was much smaller from the achieved effect with only $400 \mathrm{mg}$ per day beclomethasone among non-smokers with asthma. There was a similar unwanted and inappropriate response obtained in a treatment with fluticasone propionate at a dose of $1000 \mathrm{mg}$ per day. Even the use of oral prednisolone did not give the desired effects among asthmatic smokers. Furthermore, two other randomized controlled studies among smokers with asthma, proved that the effectiveness of the therapy is disrupted after a short period of treatment with inhaled or oral corticosteroids (Chalmers et al., 2002; Chaudhuri et al., 2003).

Table 2. FEV1 values before examination

\begin{tabular}{|c|c|c|c|c|c|}
\hline \hline \multicolumn{1}{c}{ Mean } & \multicolumn{2}{c}{ Mean } & \multicolumn{3}{c}{ Valid N Valid N Std. Dev. Std. Dev. } \\
\hline 85.04545 & 84.93750 & 22 & 16 & 3.199364 & 3.567796 \\
\hline
\end{tabular}

FEV1 - Forced Expiratory Volume in 1 second, M\% - mean value expressed in percentage of predicted values, $\mathrm{SD} \%$ - standard deviation expressed in percentage of predicted values, Mann-Whitney $\mathrm{U}$ test $(\mathrm{p}=0.9286)$

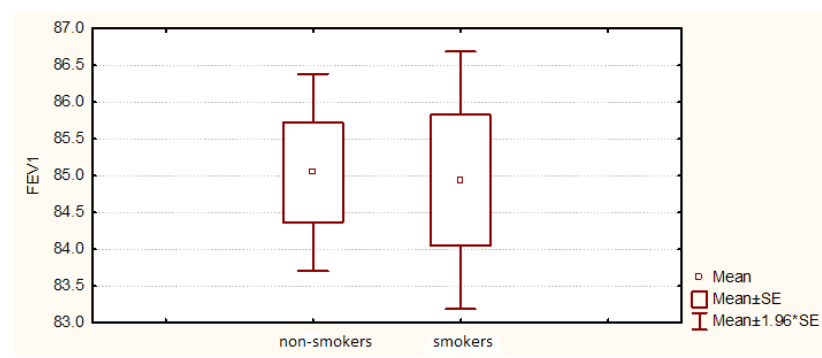

Fig. 3. FEV1 values before the examination. 
Table 3. FEV1 values after therapy

\begin{tabular}{|c|c|c|c|c|c|}
\hline \hline \multicolumn{1}{c}{ Mean } & \multicolumn{4}{c}{ Mean } & \multicolumn{3}{c}{ Valid N Valid N Std. Dev. Std. Dev. } \\
\hline 93.18182 & 85.81250 & 22 & 16 & 4.182006 & 3.290770 \\
\hline
\end{tabular}

FEV1 - Forced Expiratory Volume in 1 second, M\% - mean value expressed in percentage of predicted values, $\mathrm{SD} \%$ - standard deviation expressed in percentage of predicted values,

Mann-Whitney U test $(\mathrm{p}=0.0000)$

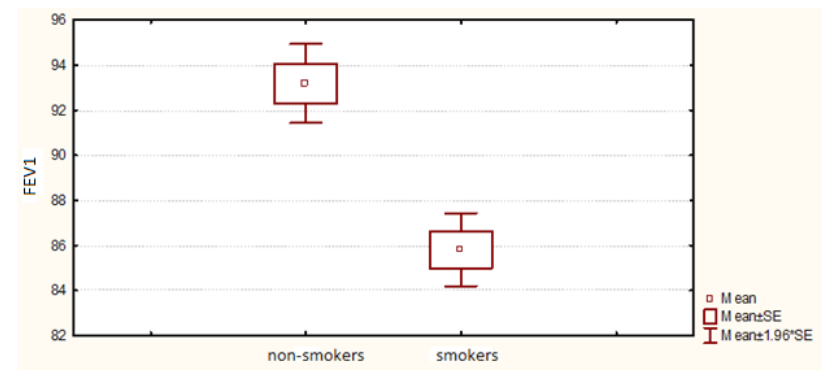

Fig. 4. FEV1 values after 6 weeks of therapy with fluticasone propionate.

According to Chauduri and his coworkers (Chauduri et al., 2006), managing asthma among smokers should result in encouragement to quit smoking, early initiation of increased use of inhaled corticosteroids, use of a combined therapy, use of antagonists of leukotriene receptors or providing high doses of inhaled steroids and/or oral steroid therapy. The author gives these recommendations based on the fact that quitting smoking improves the lung function (improved values of FEV1 before the inhalation of salbutamol, as well as persistence of the positive effect after 1,3 and 6 weeks). During a course of oral prednisolone, there was an increase of $15 \%$ in FEV1 after 6 weeks and an increase of $22 \%$ in FVC $(850 \mathrm{ml})$. It should be emphasized that the experimental group was treated with medium sized doses of inhaled corticosteroid.

In smokers with asthma, new effective therapies that are being investigated are: anti IL8, anti IL $1 \beta$, anti TNFa, $\mathrm{NF} \kappa \mathrm{B}$ inhibitors, PDE4 inhibitors, LTB4 inhibitors, development of improved inhalers, more secure steroids with higher doses and/or therapy with IFNa (Global Initiative for Asthma, GINA, 2017, Braganza et al., 2008; Barns 2003). In the treatment of the asthmatics that smoke, a creation of new drugs which will ease smoking cessation, as well as vaccines, is expected.

\section{Conclusions}

This survey verifies the assumption that the therapeutic response towards inhaled corticosteroids is reduced among the asthmatic smokers compared to the asthmatic non- smokers, despite the several weeks of treatment.

The test for determination of the lung function (FEV1) had worse results among asthmatic smokers.

There was an altered therapeutic response towards inhaled corticosteroids in average doses which it was not sufficiently expressed among asthmatics who smoke.

Among smokers with asthma, other treatment modalities are needed, like increasing the dose of inhaled corticosteroids, use of combined bronchodilator/ corticosteroid therapy and/or adding low doses of aminophylline.

\section{References}

Apostol, G.G., Jacobs, D.R., Tsai, A.W., Crow, R.S., Williams. D.O., Townsend, C, M., Beckett, S, W., 2002. Early life factors contribute to the decrease in lung function between ages 18 and 40: the Coronary Artery Risk development in young adults study. American Journal of Respiratory and Critical Care Medicine. 166(2):166-172.

BTS/SIGN, British Thoracic Society and Scottish Intercollegiate Guidelines Network. 2003. British guideline on the management of asthma. Thorax; 58:(suppl 1):1-94.

Barnes, P., Pedersen,S., Busse, W. 1998. Efficacy and safety of inhaled corticosteroids. New developments. Am. J. Respir. Crit. Care Med. 157:51-53.

Barns, B.C., Ulrik, S.Ch. 2015. Asthma and adherence to inhaled corticosteroids: current status and future perspectives. Respiratory Care 60(3): 455-468.

Braganza, G., Chaudhuri, R., Thomson, N.C. 2008. Treating patients with respiratory disease who smoke. Ther.Adv. Respir. Dis. 2(2):95-107.

Barns, P.J. 2003. Theophylline: new perspectives on an old drug. Am. J. Resir.Crit. Care Med.167:813-818.

Chaudhuri, R., Livingston, E., McMahon, A. D., Lafferty, J., Fraser, I., Spears, M., McSharry, C. P. and Thomson, N. C. (2006) Effects of smoking cessation on lung function and airway inflammation in smokers with asthma. American Journal of Respiratory and Critical Care Medicine. 174(2), pp. 127-133.

Chaudhuri, R., Livingston, E., McMahon, A. D., Tomson, L., Borland, W., Thomson, N. C. (2003) Cigarette smoking impairs the therapeutic response to oral corticosteroids in chronic asthma. Am. J. Resp.Crit. Care Med.168: 1308-11.

Chalmers, G., MacLeod, K., Thomson, L., Little, S., McSharry, C. Thomson, N.C. (2001) Smoking and airway inflammation in patients with mild asthma. Chest 120: 1917-1922.

Chalmers, W.G., Macleod, J.K., Little, A.S., Thomson, J.L., McSharry, P.C.,Thomsonet, C. N., 2002. Influence of cigarette smoking on inhaled corticosteroid treatment in mild asthma. Thorax. 57:226-230.

Global Health Observatory data (GHO). Prevalence of tobacco smoking. 2015; http://www.who.int/gho/tobacco/use/en/

Global Initiative for Asthma (GINA), GINA Report 2017, Global Strategy for Asthma Management and Prevention, updated 2016; http://www.ginasthma.org

Lanes, S., Garcia, R. L., Huerta, C. 2002. Respiratory medications and risk of asthma death. Thorax. 57:683-686.

National Heart, Lung and Blood Institute and world Health Organization. National Asthma Education Program: 
executive summary. Bethesda, 1997. Publication no 9745051.

Pedersen, B., Dahl, R., Karlstorm, R. Peterson, C.G., Venge, P., 1996. Eosinophil and neutrophil activity in asthma in one year trial with inhaled budesonide. Am. J. Resp.Crit .Care Med.153: 1519-1529.

Thomson, N.C., Chaudhuri, R., Livingston E., 2004. Asthma and cigarette smoking. Eur. Resp. Journal. 24:822-833.

Tamimi, A., Serdarevic, Dz., Hanania, A.N., 2012. The effects of cigarette smoke on airway inflammation in asthma and COPD. Respiratory Medicine; 106, 319-328.

Thomson, N.C. and Spears, M. (2005) The influence of smoking on the treatment response in patients with asthma. Current Opinion in Allergy and Clinical Immunology, 5, pp. 57-63.
Tomlinson, J.E.M., McMahon, A.D., Chaudhuri, R., Thompson, M.J., Wood, F.S., Thomson, C.N. 2005. Efficacy of low and high dose inhaled corticosteroid in smokers versus nonsmokers with mild asthma. Thorax. 60:282-287.

Tønnesen, P., Carrozzi, L., Fagerström, .KO., Gratziou, C., Jimenez-Ruiz, C., Nardini, S., Viegi, G., Lazzaro, C., Campell, I.A., Dagli, E., West, R. 2007. Smoking cessation in patients with respiratory diseases: a high priority, integral component of therapy. Eur. Respir. J. 29(2):390-417.

Viegi, G., Matteelli, G., Annesi, I., 2003. Epidemiology of asthma. Eur. Respir. Mon. 23:1-25.

\title{
Изменет терапевтски одговор кон инхалативни кортикостероиди кај астматичари - пушачи со лесна астма
}

\author{
Зоран Арсовски ${ }^{1 *},{ }^{1}$ Дејан Докиќ, Златица Гошева ${ }^{1}$, Елена Ј. Јанева ${ }^{1}$, \\ Анита Арсовска², Виктор Исјановски

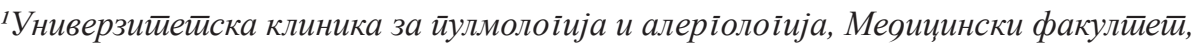 \\ Универзииеей Св. Кирил и Мейояиј, Скойје, Мајка Тереза, 17, 1000 Скойје, Р. Макеоонија

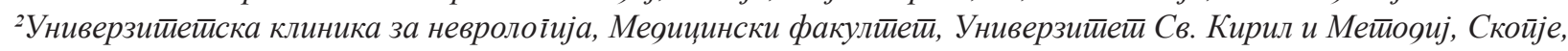 \\ Мајка Тереза, 17, 1000 Скойје, Р. Макеяонија

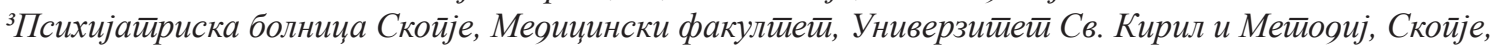 \\ Пролеиеерска бб, 1000 Скойје, Р. Макеяонија
}

Клучни зборови: астма, спирометрија, инхалаторни кортикостероиди

Изложеноста кон димот на тутун може да биде причина за бронхоконстрикција и акутен напад на астма. Астматичарите кои пушат имаат инсуфициентен терапевтски одговор кон стандардната терапија и незадоволително подобрување на респираторната функција.

Во рандомизирана паралелна студија, беше одреден терапевтскиот одговор кон инхалаторен fluticasone propionate во доза од $250 \mu \mathrm{g}$ два пати на ден кај 38 астматичари со лесна астма, пушачи и непушачи. Како лек за итна помош беше користен по потреба кратко делувачки 32 агонист (salbutamol) во доза од $0.1 \mathrm{mg} /$ во една инхалација. Кај пациентите астмата беше докажана со позитивен метахолински тест и/или позитивен бронходилататорен одговор од $>12 \%$ co $\geq 200 \mathrm{ml}$ зголемување на форсираниот експираторен волумен во 1 секунда (FEV1). Тие беа рандомизирани во две групи според пол, возраст и почетни вредности на FEV1. Тестот за одредување на белодробната фунција (спирометрија) беше направен пред и по 6 неделен третман со fluticasone propionate кај пациенти кои претходно не користеле кортикостеоидна терапија.

Во групата на астматичари - непушачи беше добиен статистички значаен одговор $(\mathrm{p}<0.05)$ по терапијата со fluticasone propionate. Позитивниот ефект изостана во групата на астматичари - пушачи. Иако процентот на зголемување на вредностите на FEV1 беше мал, истиот беше задоволителен поради почетните вредности на FEV1 кај пациентите со лесна астма.

За да се дефинира изменетиот терапевтски одговор кон инхалаторните кортикостероиди кај астматичари - пушачи потребни се повеќе студии кои ќе го одредат и астма симптом скорот, бројот на ноќни будења поради астмата, астма егзацербациите и честотата на користење на терапијата за итна помош. 
